\title{
精囊囊状拡張症扣よびその分類について
}

\author{
藤沢市民病院泌尿器科 \\ 岩崎皓広川信 \\ 横浜市立大学医学部泌尿器科 \\ 穂坂 正彦 岩本 晃明 木下 裕三 \\ 藤沢市民病院中検病理 \\ 松下和彦
}

\section{STUDY OF CYSTIC DILATATION OF THE SEMINAL VESICLES AND ITS CLASSIFICATION}

\author{
Akira Iwasaki, MIakoto Hirokawa, Masahiko Hosaka*, Teruaki Iwamoto**, \\ Yuhzo Kinoshita* and Kazuhiko Matsushita** \\ Department of Urology, Fujisawa City Hospital \\ *Department of Urology, Yokohama City University, School of Medicine \\ **Department of Pathology, Fujisawa City Hospital
}

We experienced 3 cases with characteristic findings of the vesiculograms, which were regarded as the anomalies different from so-called seminal vesicle cysts, and designated as ${ }^{66}$ cystic dilatation of the seminal vesicles", Its definition was demonstrated by the classification of the cystic lesions of the seminal vesicles.

These 3 patients with complaint of childlessness, whose semen analyses showed no or few sperms and whose histological findings of the testes showed normal spermatogenesis, were diagnosed to have obstructive azoospermia. In these 3 patients, epididynovasostomy, implantation of artificial spermatocele and retrograde dilatation of the ejaculatory duct were performed as the treatment, respectively。

Conception was successfully obtained in the patients who was treated with retrograde dilatation of the ejaculatory duct.

Finally, it was suggested that "cystic dilation of the seminal vesicles" should be classified as unique disorder based on the findings of the vesiculograms and its characteristics besides the following two characteristics which were (1) involvement of bilateral sides of the seminal vesicles and (2) complication with polycystic kidney.

要旨：特異的な精囊造影像をもつ 3 症例の経験から, これらをいわゆる精襄囊胞とは異なる独立した疾 患と考光,『精囊囊状拡張症』之呼ぶと共に, 精囊の囊胞性疾患の臨床的な分類を試み, この面からその 特徴について論じた。

自験例はいずれも不妊を主訴として来院し, 精液検査にて無精子症を, 辠丸生検にてほぼ正常の造精 機能を示したいわゆる閉塞性無精子症としてとらえられた。それ故, 治療法として, それぞれ副鼻丸精 管吻合術。人工精液瘤造設術。逆行性の射精管の拡張が行なわれたが。逆行性の射精管の拡張を施行し た症例にのみ妊娠の成立をみた。

また, 『精囊囊状拡張症』は，その精囊造影像の特徵的な形態以外に，(1）両側に変化を伴ならこと, （2）囊胞腎の合併を有すること，という2つの特徵により，独立した疾患として分類されるべきものと 考兄られた。 


\section{緒言}

精囊の囊胞性病変は複雑であり, 種々の病変が混在 している. 今迄にもいくつかの分類が扔こなわれてい るが，その 1 つに『精囊囊状拡張症』がある。単なる 精囊囊胞と異なり両側の精囊の囊胞状拡張を示す病変 である。著者らは，男子不妊症の検査をすすめる中で， 3 例の『精囊豪状拡張症』を診断した。これら 3 症例 の臨床像を解析するとともに，精囊の囊胞疾患につい て検討し，臨床的分類を和こなったので報告する。

\section{症例}

\section{症例 1 O.Y. 35歳}

4 年 7 力月の不妊歴を主訴として来院。精液所見は 無精子症（精液量 $3.0 \mathrm{ml}$ )であったが, 左右の辠丸容積 は正常大 $(25 \mathrm{ml})$ を示した。血中ホルモン值は，testosterone $5.1 \mathrm{ng} / \mathrm{ml}$, LH $13 \mathrm{mIU} / \mathrm{ml}$, FSH $6.8 \mathrm{mIU} / \mathrm{ml}$ と正常範囲内にあり，囯丸生検の所見ではほぼ正常の 造精機能を示していた。精囊造影において造影剤の膀 胼内への溢流と両側精囊の囊胞状拡張を認めた（Fig. 1)。ぬた，経静脈性腎孟造影（IVP）（Fig. 2）および computed tomography（CT)（Fig. 3）により, 囊胞 腎の合併を認めている。陰囊試験切開により, 両側の 副闰丸から精管にかけての狭窄部と，そこから近位側 の拡張を認めた。この部の閉塞を原因とする無精子症 の可能性を考光, 狭窄部位を切除後, 副睾丸精管吻合 術を施行した。組織学的にも特に炎症像を示さず，拡

Fig. 1 Vesiculogram in case 1 demonstrates cystic dilatation of bilateral seminal vesicles and contrast media into the bladder.

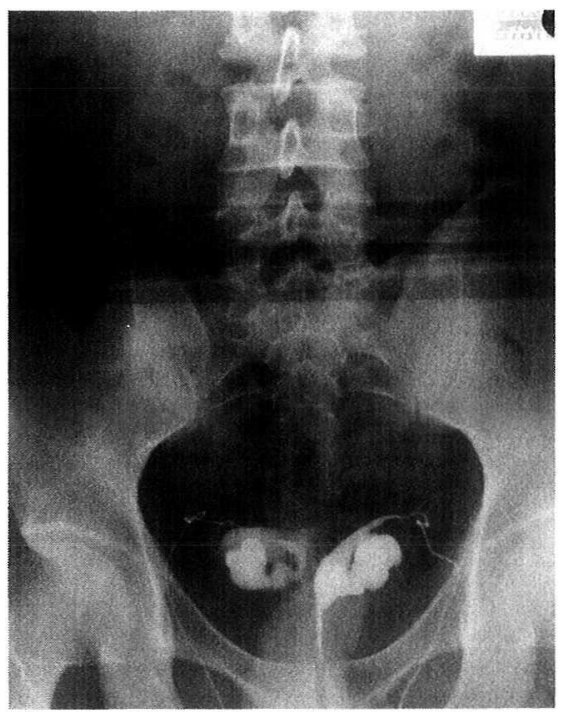

Fig. 2 Intravenous pyelography in case 1. Typical urographic deformity of polycystic kidney is shown.

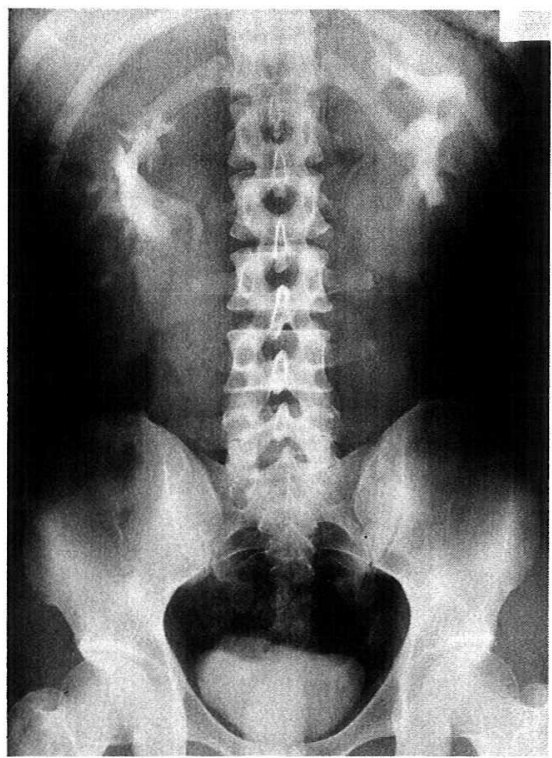

Fig. $3 \mathrm{CT}$ scan in case 1 . The same finding as shown in Fig. 2.

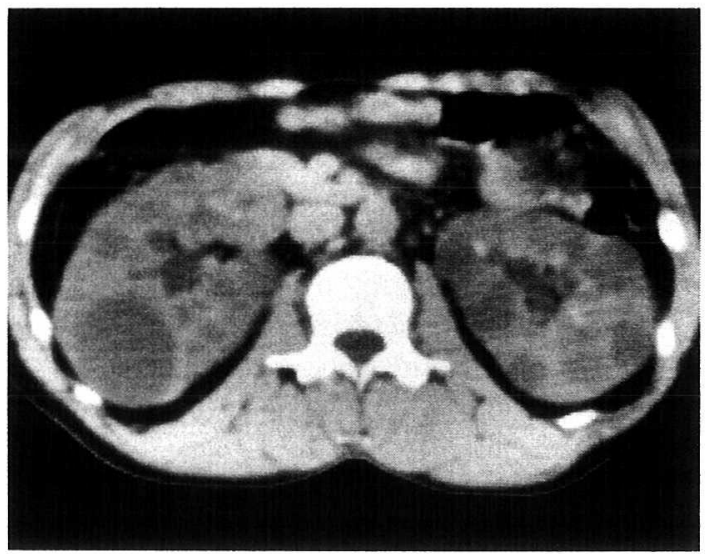

張した内腔に多数の精子と脱落した上皮を認め，この 部位の閉塞をらかがわせた。しかし，手術後の精液検 查では 1 回のみ精子が確認されたが，それ以後は無精 子症である。

\section{症例 2 M.S. 31歳}

3 年 7 カ月の不妊歴を主訴として来院. 精液所見は 無精子症 (精液量 $1.0 \mathrm{ml}$ ) であったが, 両側の辠丸容積 は正常大 $(18 \mathrm{ml})$ を示した。血中ホルモン値は testosterone $5.7 \mathrm{ng} / \mathrm{ml}$, LH $1.2 \mathrm{mIU} / \mathrm{ml}$, FSH $12.6 \mathrm{mIU} /$ 
$\mathrm{ml}$ であった。辠丸生検の所見は，ほぼ正常の造精機能 を示した。精囊造影に执いて，両側の精囊の囊胞状拡 張を認め, 造影剤の膀胱への溢流は認められなかった (Fig. 4)。ぬた，CT 像にて囊胞を確認できないもの の, IVP, CT ともに両側の腎腫大を認め (長径 $17 \mathrm{~cm}$ ),

Fig. 4 Vesiculogram in case 2 reveals marked dilatation of seminal vesicles and vas deferens in both sides.

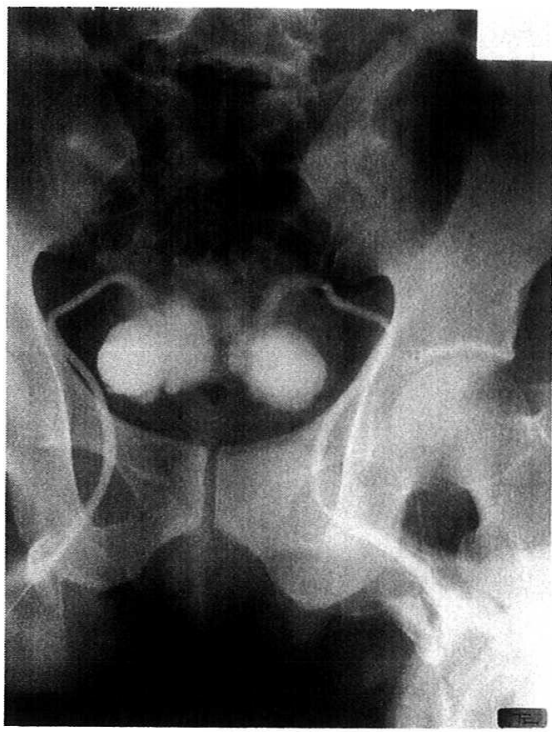

Fig. 5 IVP in case 2 shows enlarged both kidneys with calyceal deformity.

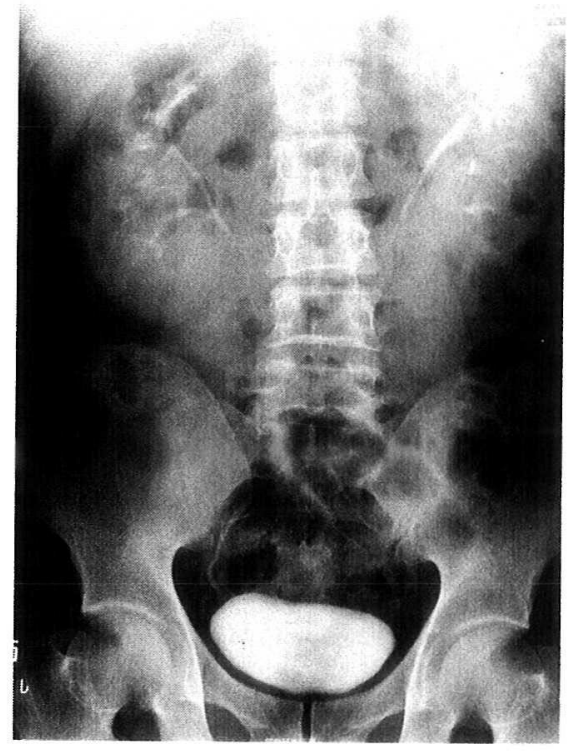

延長した腎杯像より考学て囊胞腎を強く疑わせる所見 が得られた（Fig，5，6)。陰囊試験切開により，暗赤色 泥状液を含み，極度に拡張した精管を認めた。また， 副睪丸尾部が囊胞状に拡張を示して未り，このため肉 眼的には副羙丸と精管との間の交通はないものと考觉 られた (Fig. 7)。しかし, 組織学的検討では, 副辠丸 に一部拡張を多るが，狭窄部も基本的構造は保たれて おり, 内腔に少数の精子も認められた。すなわち，二

Fig. 6 CT scan in case 2 shows both kidneys with scattered small radiolucent areas and no typical polycystic disease.

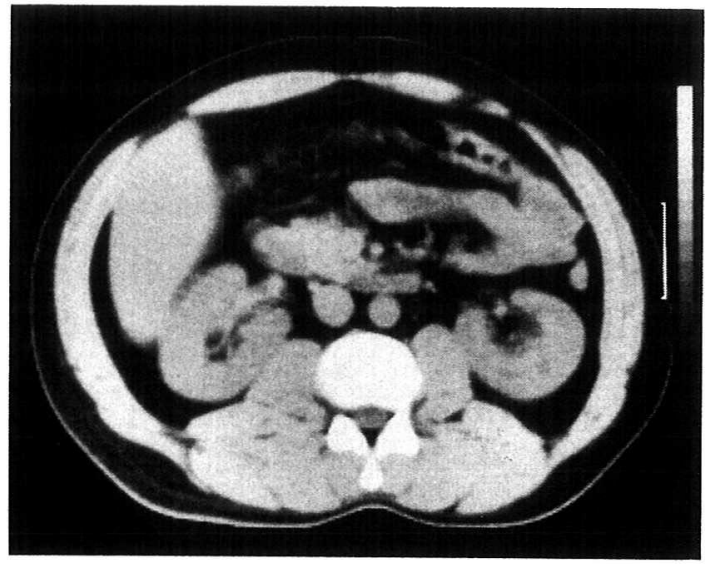

Fig. 7 Photograph at exploration in case 2: Arrow shows narrow segment between markedly dilated vas deferens and cyst of epididymal tail.

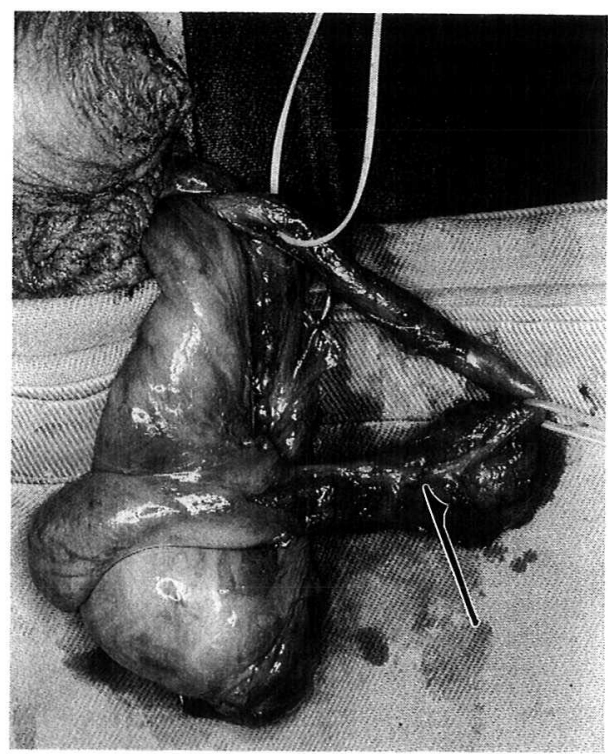


次的変化のみにより生じた囊胞と考えるよりは，先天 性の病変が基礎に存在するものと考兄られた（Fig. 8). 遠位端の閉塞もあることから人工精液瘤造設術の 適応と考兄, goatex vascular graftによる人工精液 瘤1を造設したが，現在まで精子を採取できていない。

\section{症例 3 M.K. 41歳}

11年の不妊歴を主訴として来院。初診時, 精液検査 にて1視野に1〜2 個の精子を認めたが，その後はす べて無精子症（精液量0.8 4.0ml）であった。輧丸容 積は右側 $20 \mathrm{ml}$, 左側 $18 \mathrm{ml}$, 共に正常の粹丸硬度を示し た。血中ホルモン值は testosterone $3.68 \mathrm{ng} / \mathrm{ml}, \mathrm{LH}$

Fig. 8 Microscopic section of epididymis in case 2. See dilated epididymal tubules containing spermatozoa even in the narrow segment.

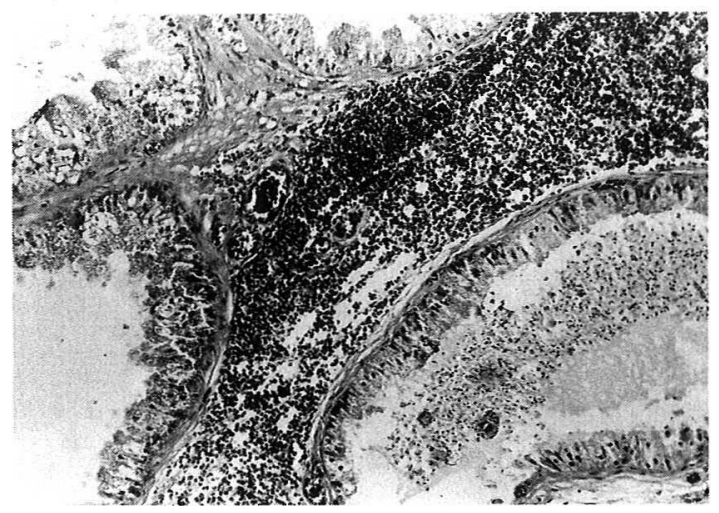

Fig. 9 Vesiculogram in case 3. See cystic dilatation of seminal vesicles and no dilatation of vas deferens.

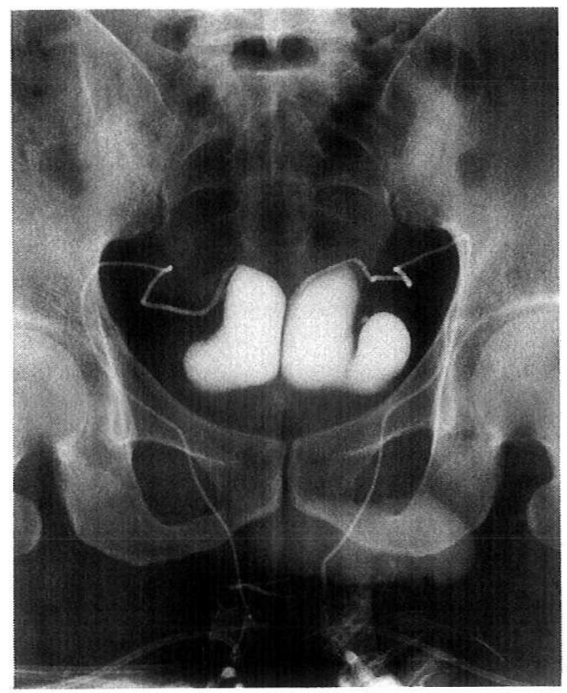

Fig. 10 CT scan in case 3 reveals multiple cysts of various sizes in both kidneys.

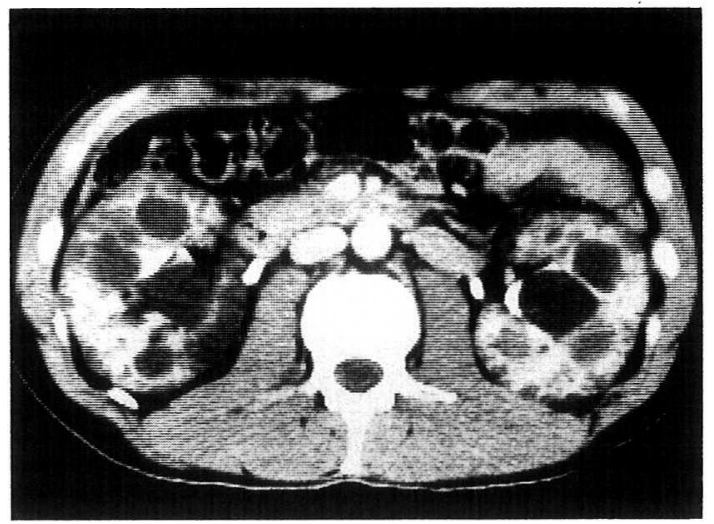

$5.8 \mathrm{mIU} / \mathrm{ml}$, FSH $6.3 \mathrm{mIU} / \mathrm{ml}$ と正常範囲内であっ た。囯丸生検の所見は，核ぼ良好な造精機能を認めた。

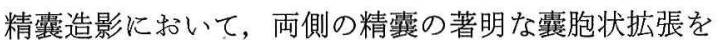
認めた(Fig. 9)。また，IVP，CTにより囊胞腎と診断 された(Fig. 10)。超音波検查下の恥骨上からの囊胞穿 刺により血清の液を $30 \mathrm{ml}$ 吸引したが, これには一部運 動性を有する精子を含んでいた。この方法で採取した 精子による配偶者間人工授精 (A.I.H.)を考学たが，患 者の苦痛が強く再施行を断念した。尿道鏡検查に损い て精丘に射精管と思われる孔があり，ここに尿管カ テーテルを挿入, 拡張後, 造影により精囊造影と同様 の所見を得た。この後, 採取した射精液中には造影剂 とともに運動性良好な精子を認めている。経過観察中, 2 力月後の精液検査では再び無精子症となっていた が, 拡張操作後約 10 力月目に妊娠 4 力月の報告を受け て扮り, その後, 満期正常分婏により挙児に成功して いる。

\section{考 察}

1）精囊囊状拡張症の名称と精囊囊胞の分類につい $\tau$

自験例と同様の精囊造影像を示す症例の報告は決し て少なくない。石神らは精管末端部の異常拡張症と呼

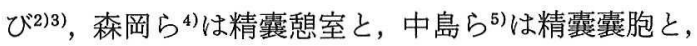
そして酒徳ら゙) は精囊の囊胞状拡張症と呼んだ。また, Colpi $ら^{7)}$ はseudocystic dysplasia of the seminal vesicles と診断し, Weintraub $ら^{8}$ は obstruction of ejaculatory duct と報告した。このように種々の名称 で呼びあらわされている。しかし，この精囊造影像は 後述する真の精囊囊胞の精囊造影像とは異なる。ぬた, 悸室と呼ぶのも妥当ではない。そして, 後天的な閉塞 
Table 1 Classification of Cystic Lesions of and around the Seminal Vesicles

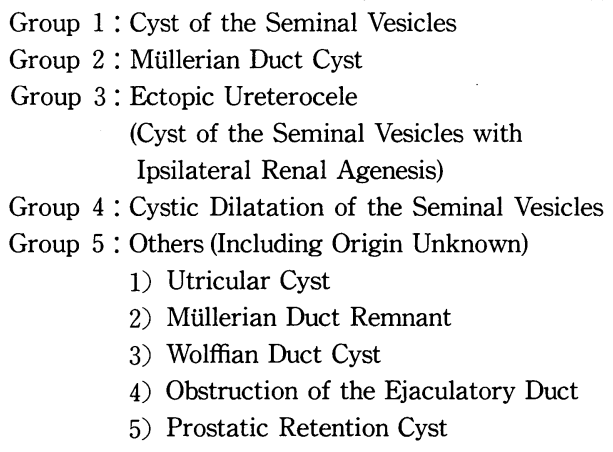

のため精囊, 精管の内圧の上昇が起こり精囊の拡張が 生じるとしても, 精囊の惒室状形態が無くなる程の内 圧の上昇が得られるとは考光難い，それ故，射精管の 閉塞，あるいは狭窄もふさわしくないまた，精囊異 常拡張症という名称は, むしろ総称として用いられて おり ${ }^{29)}$ ，的確な表現ではないと考学られる．自験例の 精囊造影像上の特徵として，（1）両側性であること， （2）数室様構造を失ない, あたか子食道における achlasia の様な形態をとること，(3) 射精管の完全な閉塞 例以外では，尿道との交通を有しており，その際には 精管自体の抎張は著明ではないこと，があげられる。 それ故, 著者らは先天的な疾患を強く示唆するこれら

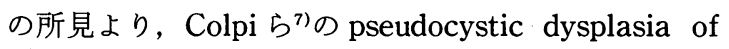
the seminal vesicle や酒徳 ${ }^{6)}$ の囊胞状払張という考 え方をとり, 精囊囊状拡張症と呼ぶことが妥当と考兄 るに到った。 そして, この精囊囊状拡張症を独立した 疾患と考光，その他の精囊㧍よび精囊周辺の囊胞性疾 患とを 5 群に分類した (Table 1)。また，Fig. 11 に内 外の報告例にみられたそれらの精囊造影像の略図を示 した. Fig. 11 をとにして 5 群の説明を試みる。

第 1 群は, 今迄に精囊囊胞あるいは精囊㮩室と呼ば れたものの大部分である. Fig. 11 の b, c，d，eをす べて含む。囊胞内の精子の有無，あるいは精囊造影に て造影されるか否かということで精囊囊胞と精囊敗室 が区別できるとされた ${ }^{9)}$. 従来なら e を惒室と呼び b,

$\mathrm{c}, \mathrm{d}$ を囊胞と呼ぶべきであろう。しかし，これらをす べて含め精霟囊胞と呼んだ. 何故なら，いずれの場合 も，お互いに，後天的に交通したものや，交通が遮断 されたものの存在を含むと考兄られからである。 た, 臨床的には判断がつき難く，一括して精囊囊胞と して報告されている例が多( ${ }^{910)}$. そして，る51つ重
Fig. 11 Schematic Vesiculograms of various Cystic Lesions of and around the Seminal Vesicles

a) Cystic Dilatation of the

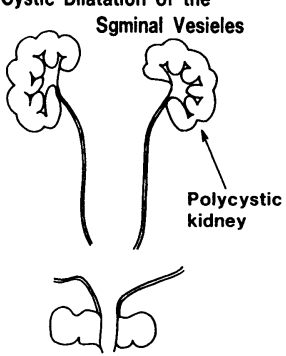

e) Seminal Vesicle Cyst

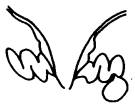

f) Miillerian Duct Cyst

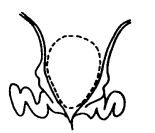

b) Seminal Vesicle Cyst

*

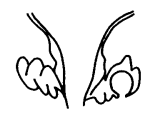

c) Seminal Vesicle Cyst

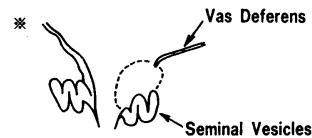

h) Utricular Cyst

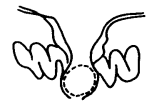

d) Seminal Vesicle Cyst

*

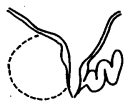

i) Obstruction of the Ejaculatory

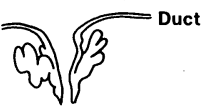

※ with or without ipsilateral renal agenesis

要な事は, これらの症例の場合, 精囊造影において両 側の精囊がほぼ正常に近い形で写し出されることが多 い'11)(Fig. 11 b，c，e). しかし，時には鎱胞が巨大で あるため，同側の精囊が描記されない症例も報告され ている ${ }^{12)}$ (Fig. 11d).

第 2 群は, Müller 氏管囊胞と呼ぶべきものである. この多くは内容液に精子を認めず，精裳造影で造影さ れないのが普通である13)(Fig. 11f)。しかし，中には, ここに射精管が開口し, 精子を含み, 精囊造影にて造 影される症例もある ${ }^{14)}$ (Fig. 11g)。 そのため不妊の原 因となりらる ${ }^{15)}$ 。これらにいくつかの名称が用いられ ている。中村ら ${ }^{16)}$ の精囊囊胞, Brooks, $\mathrm{Jr}^{17)}$ の射精管 の囊胞などである。そして, この場合にも, 両側の精 囊は精囊造影により, 正常の形で描記されている ${ }^{14) 15)}$.

第 3 群は, 本来, 異所性尿管瘤と呼ぶべきもので, 多くの精囊囊胞には同側の腎無形成を伴ならといら報 告 ${ }^{1113)}$ は, この場合を指しているものと考兄られる。す なわち, 精囊囊胞に合併した, 盲端に終った尿管の報 告18)もあることから, 腎・尿管の遺残を証明できないと 
する腎無形成を伴なら精囊囊胞も，このグループに入 れるべきと考えた。言い換えると，精囊に開口した異 所性尿管瘤の中で，腎・尿管の遺残を認めない形が腎 無形成を伴なら精囊囊胞と報告されたものと解してい る. 段階的にいくつかの呼称が必要とも考えられる9 が，著者らは一括して異所性尿管瘤（同側の腎無形成 を伴なら精囊囊胞）の項にとどめた，以上の事から， 精囊造影に打いては，ほぼ正常の精剚像を示すことも (Fig. 11b，c，e)，また，霊胞のため同側の精囊が殆ど 造影されない場合もありらる(Fig. 11d)。これは, 囊 胞の発育状態とともに，尿管が精囊の内部へ開口した か，あるいは，周辺に開口したかの違いからも生じる ものと考えている。

著者らは，第 4 群に精囊囊状拡張症を設定した。森 脇 ${ }^{4)}$, 中島 $ら^{5)}$, 佐長 ${ }^{19)}$, 酒徳 $ら^{6)}$ の報告にみられる 如く囊胞腎の合併をみる頻度は高く, 精囊の病変も両 側性であること，礊室状形態を認めない程払張をきた しており，後天的閉塞による内圧上昇だけが原因と考 え難いことなどの理由から先天的な，独立した疾患と 考えるに到った. Fig. 11 の a と i を比較すると, 後天 的閉塞を原因とすると思われる obstruction of ejaculatory duct との形状の違いが判別できる.

第 5 群は以上のグループに入らない群で，(i) utricular cyst, (ii) Müllerian duct remnant, (iii) Welffian duct cyst, (iv) obstruction of ejaculatory duct,（v）prostatic retention cyst と称されるもので ある. obstruction of ejaculatory duct は精囊造影像 より鑑別可能である，既往歷を欠くことから，先天性 のものが考兄られているが820221), むしろ, この形態的 変化は後天性に得られた内圧の上昇による变化と考兄 やすい, utricular cyst および Müllerian duct remnant は Müller 氏管囊胞と同一視されて報告される例 が多いが, hypogonadismなどを示す性分化異常を伴 ならことが多く ${ }^{22)}$ ，また, 発生学的には中肧葉起源の遺 残が囊胞を形成しただけの Müller 氏管囊胞とは, まったく異なるものとされる23). いずれも精襄造影像 には変化がないか，あるいは，内方よりの囊胞による 圧排像が認められるのみである (Fig. 11h). Wolffian duct cyst 打よび prostatic retention cystは，その襄 胞の位置, 形状より判断すべきものであるが23), 確定診 断はむしろこちらの方が困難である.

以上,精囊の囊胞性疾患の分類につき私見を述べた。 発生学的見地から生じるであろら精囊造影像の差異に 重きを置いたため, 確定診断に苦慮する症例も多いも
のと考えられるが，著者らは上記の判断により得られ た診断名で, 臨床的には充分役立つものと考えている。 加藤らは，正確な診断には組織学的検討が不可欠なも のと述べている ${ }^{12}$ が, いずれも良性疾患であり，自覚症 状の欠ける場合には，根治的外科的治療は不要であり， 場合によっては組織診断も不必要となる ${ }^{11)}$.すなわち, これらの鑑別診断には精䣼造影に加えて, 膀胱造影, 穿刺による囊胞造影, CT, 超音波診断, 膀脱尿道鏡を 行なえば充分と考えている。

2）囊胞腎の合併について

精囊の発生は, 腎・尿管の発生に遅れ, 胎生期第 13 週に尿生殖洞の傍で, Wolff 管の遠位部の膨出により 始まり, 稳室形成を重㱛て胎生期第 7 力月に完成され $る^{24)}$. 一方, 軲胞腎の発生の要因に遺伝子が想定されて 扣り ${ }^{25)}$, 合併する肝囊胞も, 霊胞の発生部位の検討から 同一の要因が考えられている。そして，囊胞腎には， 肝, 膵, 肺, 脾, 卵巣, 殬丸, 甲状腺, 子宮, 膀胱な

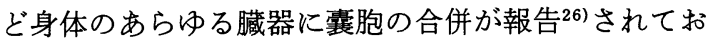
り, 同様の機転で, Wolff 管の末端にて, 精囊の正常の 発生が障害され，囊胞状拡張をさたす可能性も充分考 えられる。をた，Holsclaw らは， cystic fibrosisにみ られる精囊の囊胞状変化が, 新生児剖検例よりの検討 から, 胎生期にすでに存在する先天性のものと推測し ている ${ }^{27)}$.このことは, 精囊囊状拡張症の分泌, 貯留に より形成されるものではなく，先天性に形成される可 能性を示唆している. そして, 前述した森脇ら ${ }^{4)}$, 中島 $ら^{5)}$ ，佐長 ${ }^{199}$ ，酒徳 ${ }^{6)}$ の報告からも，自験例の如き 精霊造影像を有する症例が囊胞腎を合併する確率は非 常に高いものと考えられる. 以上のことから, 今後, 同様の所見が得られた場合，上部尿路の詳細な検討が 望まれる。

3）精囊囊状抎張症の治療について

本症例は不妊を主訴として来院している，他の症状 もなく，また，直腸内触診でもはっきりとした腫瘤は 触知されていない，無精子症として，造精機能の保た れている症例に精囊造影を施行し見出された症例であ る。それ故, 治療法は精子をいかにして得るかにかかっ てくる，手術的には，石神がこのような症例に縫縮術 を行ない妊娠に到らしめたと報告している3). また，前 立腺部尿道に経尿道的に切開を加学る方法も報告され ている. 射精液中に精子が出現し ${ }^{8)}$, 妊娠に成功したと の報告 ${ }^{20)}$ ある。逆行性の副睪丸炎を生じる危険を伴 ならが, 試みてみるべき1つの方法と考劣る。しかし， Silber は obstruction of ejaculatory duct の症例で, 
閉塞により内圧の高まった場合, 近位側に二次的な狭 窄あるいは閉塞部位を生じるとし，この部位の形成術 も同時に必要であると述べている ${ }^{21)}$. 症例 (1) および （2）は，試験切開によりこのような閉塞部位を見せて いる，特に症例(2)は，まったく尿道との交通がなく， 精管も太く拡張し, 副辠丸尾部に狭窄を生じ, 更に近 位側の著明な拡張のみられた症例である。遠位端の完 全閉塞のため, 人工精液瘤造設術の適応症例 ${ }^{1)}$ 之考光, goatex vascular graftによる人工精液瘤の造設を試 みた。しかし，現在まで精子の獲得に成功していない。 症例 (1) の場合は, 術中の精囊造影により尿道までの 通過を確認できたため, この閉塞部位を切除後, 再吻 合術が施行された。手術後の精液検査で一度, 少数の 精子が見出されているが, その後, 現在まで無精子症 である。症例（3）に対しては, 最初, 超音波下に経膀 胱的に恥骨上より精震を穿刺した。穿刺液には, 多数 の赤血球と共に運動性をもつ精子を認めたが, 頻回の 採取が難しく,この方法による A.I.H. は断念せざるを 得なかった。次いで，尿道鏡下に逆行性に射精管内に 尿管カテーテルを插入，挔張を行なった。一時的に精 液中に運動性精子が少数ながらも認められるよらに なったが，2 カ月後には再び無精子症となっていた。 しかし, この後, 配偶者の妊娠が確認されており, 非 侵襲的なことから，この方法は，まず最初に試みるべ き方法と考えられた。

\section{文献}

1）岩崎 晧, 穂坂正彦, 木下裕三, 岩本晃明, 長田久 文, 広川信: Goatex vascular graft を用いた人 工精液瘤造設術の試み。日本不妊会誌, 31,116 $-121,1986$.

2）石神襄次, 加古 賢, 矢田文平, 吉田秀政, 中野順 道: 精囊腺並びに精管末端部の異常払張症に就 て. 泌尿紀要, 6, 792-804, 1960.

3）石神襄次：精襄腺 $レ$ 線診断の意義. 臨泌， 28, $13-21,1974$.

4）森脇 宏, 結縁繁夫：精囊腺㕷室についてーとく にその分類について一，日泌尿会誌，53，43-47, 1962.

5）中島哲雄, 柳瀬功一：精囊腺豊胞の 2 例. 日泌尿会 誌, 49, 731-737, 1958.

6）酒徳治三郎，桐山旁夫，佐長俊昭，上領頼啓，小金 丸佰夫，平山 嗣：多発性哓胞腎を合併した精豊 腺および精管末端部囊胞状払張について。西日泌 尿, 35, 12-17, 1973.

7) Colpi, G.M., Ballerini, G. and Zonollo,; A.: Ultrasonography of the seminal vesicle in infertility. Prog. Repord. Biol. Med., Vol. 12, p. 124
-142, Karger, Basel, 1985.

8) Weintraub, C.M.: Transurethral drainage of the seminal tract for obstruction, infection and infertility. Brit. J. Urol., 52, 220-225, 1980.

9）松岡 啓, 中川克之, 野田進士：精囊腺囊状拡張に ついて. 西日泌尿，39，713-724，1977.

10）田近栄司, 白井千博：精霊囊胞の 2 例. 臨泌, 34, 581-583, 1980.

11) Korobkin, M. and Cooperman, L.R.: Vesiculographic findings in cysts of the seminal vesicle. Radiol., 114, 571-574, 1975.

12）加藤哲郎, 宮川征男, 桑原正明, 熊谷郁太郎, 三浦 邦夫, 根本良介：巨大な精囊腺霊腫. 泌尿紀要, 20, 81-87, 1974.

13) Lucey, D.T., Mcaninch, J.W. and Bunts, R.C.: Genital cysts of the male pelvis : Case report of müllerian and ejaculatory duct cysts in the same patients. J. Urol., 109, 440-443, 1973.

14）三浦 猛, 高橋 剛：ミューラー管裳腫に開口し た精管開口異常の 1 例. 泌尿紀要, 28, 173-176, 1982.

15) Sharlip, I.D.: Obstructive azoospermia or oligoozospermia due to Müllerian duct cyst. Fertil. Steril., 41, 298-303, 1984.

16）中村正広, 北村憲也, 辻本幸夫, 櫻井 晶, 片岡喜 代徳：精囊腺霊胞の 1 例. 臨泌, 35, 1019-1021, 1981.

17) Brooks, R.T. Jr.: Cyst of the ejaculatory duct : Case report. J. Urol., 101, 881-883, 1969.

18) Fuselier, H.A. Jr. and Peters; D.H.: Cyst of seminal vesicle with ipsilateral renal agenesis and ectopic ureter : Case report. J.. Urol., 116, 833-835, 1976.

1n）佐長俊昭, 神崎賴啓：精裳腺囊胞を合併した先天 性囊胞腎の 4 例．西日泌尿，33，630，1971.

20) Porch, P.P. Jr.: Aspermia owing to obstruction of distal ejaculatory duct and treatment by transurethral resection. J. Urol., 119, 141-142, 1978.

21) Silber, S.J.: Ejaculatory duct obstruction. J. Urol., 124, 294-297, 1980.

22) Devine, C.J. Jr., Gonzalez-serva, L., Stecket, J.F. Jr., Devin, P.C. and Horton, C.E.: Utricular configuration in hypospadias and intersex. $\mathrm{J}$. Urol., 123, 407-411, 1980.

23) Van Poppel, H., Vereecken, R., De Geeter, P. and Verduyn, H.: Hemospermia owing to utricular cyst: embryological summary and surgical review. J. Urol., 129, 608-609, 1983.

24) Narbaitz, R.: Embryology, anatomy, and histology of the male sex accessory glands. "Male accessory sex organs : structure and function in 
mammals" p. 3-, David Branders, New York Academic Press, 1974.

25) Potter, E.L.: Type III cystic kidney: combined ampullary and interstitial abnormality. "Normal and abnormal development of th kidney" p. 182-, Chicago, Year Book Meedical Pub. Inc., 1972.

26) Hamburger, J., et al.: Polycystic disease of the kidney. "Nephhrology" Vol. II, p. 1070-, W. B. Saunders, 1969.

27) Holsclaw, D.S., Perlmutter, A.D., Jockin, H. and Schwachman, H.: Genital abnormalities in male patients with cystic fibrosis. J. Uorl., 107, 568-574, 1971.

（1988年 3 月 1 日受理） 